Research Article

\title{
Performance of Methyl-5-Benzoyl-2-Benzimidazole Carbamate (Mebendazole) as Corrosion Inhibitor for Mild Steel in Dilute Sulphuric Acid
}

\author{
F. O. Edoziuno $\mathbb{D}^{1},{ }^{1}$ A. A. Adediran $\mathbb{D}^{2},{ }^{2}$ B. U. Odoni, ${ }^{1}$ M. Oki $\mathbb{D}^{2},{ }^{2}$ P. P. Ikubanni, ${ }^{2}$ \\ and O. Omodara ${ }^{3}$ \\ ${ }^{1}$ Department of Metallurgical Engineering, Delta State Polytechnic, Ogwashi-Uku, Ozoro, Nigeria \\ ${ }^{2}$ Department of Mechanical Engineering, Landmark University, PMB 1001, Omu-Aran, Kwara, Nigeria \\ ${ }^{3}$ Department of Metallurgical and Materials Engineering, Federal University of Technology Akure, PMB 704, Akure, \\ Ondo, Nigeria
}

Correspondence should be addressed to F. O. Edoziuno; francisedoziuno@gmail.com, A. A. Adediran; dladesoji@gmail.com, and M. Oki; makanjuola.oki@lmu.edu.ng

Received 5 February 2020; Revised 22 April 2020; Accepted 2 May 2020; Published 24 June 2020

Academic Editor: Ghadir A. El-Chaghaby

Copyright $\odot 2020$ F. O. Edoziuno et al. This is an open access article distributed under the Creative Commons Attribution License, which permits unrestricted use, distribution, and reproduction in any medium, provided the original work is properly cited.

\begin{abstract}
The inhibitive effect of mebendazole (MBZ) on the corrosion of low-carbon steel in $\mathrm{H}_{2} \mathrm{SO}_{4}$ was investigated by gravimetric and electrochemical techniques as well as examination of specimens in the scanning electron microscope with attached energy dispersive X-ray spectrometer (EDS). From gravimetric analysis, the highest inhibition efficiency of about $96.6 \%$ was obtained for $1.0 \mathrm{~g}$ of inhibitor in $\mathrm{H}_{2} \mathrm{SO}_{4}$ solution at $24 \mathrm{~h}$, while with longer exposure times of between 72 to $120 \mathrm{~h}$, the efficiencies averaged between 92 and 95\%. Tafel extrapolations from the polarization curves showed that $1.0 \mathrm{~g}$ MBZ gave a maximum inhibition efficiency of approximately $99 \%$ for the investigation conducted at $30^{\circ} \mathrm{C}$, whereas $1.5 \mathrm{~g}$ of $\mathrm{MBZ}$ gave a maximum inhibition efficiency of about $85 \%$ at $60^{\circ} \mathrm{C}$. Inhibition efficiency increased with increasing concentrations of MBZ and decreased at elevated temperatures. The inhibitive action was attributed to physical adsorption of MBZ species on the mild steel surface which followed the Langmuir adsorption isotherm. MBZ performed as a mixed-type inhibitor on mild steel in dilute $\mathrm{H}_{2} \mathrm{SO}_{4}$.
\end{abstract}

\section{Introduction}

In order to mitigate corrosion, an effective and flexible means is through the use of corrosion inhibitors $[1,2]$. Any chemical or combination thereof that reduces corrosion rates without significant reactions with the components of the environment is an inhibitor [3-5]. Usually all major industries involved in processing of chemicals normally consider the use of inhibitors as first line of defence against aggressive attack on plant equipment. Mild steel finds major application in a wide range of industries because of its excellent physical and mechanical properties, low cost, and availability, but it has very low corrosion resistance in aggressive service environments [6,7]. A large number of researches have focussed on various organic/inorganic corrosion inhibitors for mild steel in acidic environments with varying inhibition efficiencies [8-15]. Corrosion inhibitors have found major use in closed systems with good circulation and controlled inhibitor concentrations, which may include cooling water recirculation systems, oil production and refining, industrial acid cleaning, and acid pickling of steel components. However, inorganic inhibitors such as chromates and zinc salts have suffered major setbacks in their usage as a result of toxicity and have largely been replaced with organic inhibitors $[16,17]$. Therefore, practical selection criteria of corrosion inhibitors from huge varieties of inorganic and organic chemicals which have inhibiting properties do not depend solely on their inhibition efficiencies but also on the safety of use, economic constraints, and compatibility with other chemicals in the system and environmental concerns [18-20]. Some of the most effective organic inhibitors 
include amines, sulphur compounds such as thioethers, thiourea, thioalcohols, hydrazine and thioamides, and heterocyclic nitrogen compounds [21]. Organic compounds are good inhibitors especially when they have functional electron-rich centres such as pi-electron in triple or conjugated double bonds and the presence of aromatic rings in their structures which serve as major adsorption centres [21-23].

A review of the literature revealed the use of benzimidazole derivatives as promising corrosion inhibitors for steel in various environments [7, 13, 24-31]. Benzimidazole and its derivatives have excellent pharmacological properties such as anti-bacterial, anti-fungal, anti-cancer, anthelminthic, etc. In addition, they display planar structures with anchoring sites at $\mathrm{sp}^{2}$ hybridized nitrogen carrying lone pairs of electrons coupled with aromatic rings. These and other conjugating factors make them relatively more suitable for use as environment friendly and biodegradable corrosion inhibitors [26]. The present work investigates the performance of Methyl-5-benzoyl-2benzimidazole Carbamate (mebendazole) as corrosion inhibitor for mild steel in $\mathrm{H}_{2} \mathrm{SO}_{4}$ using gravimetric analyses and electrochemical polarization techniques in addition to scanning electron microscopy examinations. Mebendazole is a synthetic benzimidazole derivative which may be nontoxic and biodegradable and has been employed in therapeutic treatments as anthelmintic drug that has the molecular formula of $\mathrm{C}_{16} \mathrm{H}_{13} \mathrm{~N}_{3} \mathrm{O}_{3}$ with a molecular weight of $295.3 \mathrm{~g} / \mathrm{mol}$.

\section{Experimental Techniques}

\subsection{Materials}

2.1.1. Test Media. The gravimetric analyses were carried out at ambient temperatures of about $30^{\circ} \mathrm{C}$ in $1.5 \mathrm{M} \mathrm{H}_{2} \mathrm{SO}_{4}$, prepared with double distilled deionized water. Wormin ${ }^{\circledR}$ Mebendazole tablets, manufactured by CADILA pharmaceutical limited, India, were purchased from NBC pharmaceutical coy at Aladja Warri, Nigeria. The tablets were ground to fine powder to increase the surface area and enhance the rate of corrosion inhibition. $100 \mathrm{ml}$ of the dilute $\mathrm{H}_{2} \mathrm{SO}_{4}$ with or without the addition of specified concentrations of mebendazole (MBZ) inhibitor which ranged from 0 as control through 0.5 to $1.0,1.5$ were utilized.

2.1.2. Test Specimens. Commercially available $16 \mathrm{~mm}$ diameter mild steel (rod with composition $\mathrm{Fe}=98.224 \%$, $\mathrm{C}=0.288 \%, \mathrm{Mn}=0.624, \mathrm{Cu}=0.268, \mathrm{Cr}=0.182, \mathrm{~S}=0.052$, $\mathrm{P}=0.051, \mathrm{Ni}=0.090, \mathrm{Al}=0.021)$ was machined to obtain specimens with dimensions $15 \mathrm{~mm}$ in thickness and $10 \mathrm{~mm}$ length. A $5 \mathrm{~mm}$ hole was made at the centre of the electrodes. The samples were mechanically ground with series of emery papers with grades from 800 to 1200 . The specimens were rinsed with distilled water, degreased with acetone, and allowed to dry before each corrosion test.

\subsection{Methods}

2.2.1. Gravimetric Measurements. Weighed specimens were totally immersed by suspension in each of the various test media in a $200 \mathrm{ml}$ closed beaker for different contact times of $24,48,72,96$, and $120 \mathrm{~h}$ in the presence and absence of MBZ inhibitor. After the various immersion periods, the test specimens were retrieved from the corroding systems and subsequently washed with distilled water, rinsed with acetone, air-dried, and re-weighed. Equation (1) $[7,14]$ describes the relationship among the corrosion rate (CR) in millimetres per year $(\mathrm{mm} / \mathrm{yr})$ and other parameters employed in this study:

$$
\mathrm{CR}=\frac{87.6 \times \mathrm{WL} \times 1000 \mathrm{mg}}{D \times A \times T},
$$

where WL is the weight loss in grams, $D$ is the density in $\mathrm{g} / \mathrm{cm}^{3}$, $A$ is the area in $\mathrm{cm}^{2}$, and $T$ is the time of exposure in hours. The $\%$ inhibitor efficiency, $\eta$, was calculated using equation (2):

$$
\eta=\frac{\mathrm{CR}_{c}-\mathrm{CR}_{i}}{\mathrm{CR}_{c}} \times 100
$$

where $\mathrm{CR}_{c}$ and $\mathrm{CR}_{i}$ are the corrosion rates in the absence and the presence of inhibitor, respectively.

2.3. Electrochemical Measurements. The polarization experiments were carried out using an Autolab potentiostat/ galvanostat VersaSTAT 4 Electrochemical System controlled from a computer by a Universal Serial Bus (USB) interface using the Versa Studio electrochemistry software package. A conventional three-electrode Pyrex glass cell was employed for the polarization measurements at $30^{\circ} \mathrm{C}$ and $60^{\circ} \mathrm{C}$, respectively. For each measurement, test specimens, with $1 \mathrm{~cm}^{2}$ of exposed areas, were employed as working electrodes with a platinum rod as counter electrode. $\mathrm{Ag} / \mathrm{AgCl}$ was used as the reference electrode with a luggin probe placed close to the working electrode. All experiments were undertaken in stagnant aerated solutions. The working electrode was immersed in the test solution for one hour until a stable open circuit potential was attained. The potentiodynamic polarization study was conducted at a potential range of $-250 \mathrm{mV}$ to $+250 \mathrm{mV}$ with respect to the corrosion potential using linear sweep technique at a scan rate of $1 \mathrm{mV} / \mathrm{s}$. The linear Tafel segments of the anodic and cathodic curves were extrapolated to equilibrium potential in order to obtain the corrosion current densities $\left(i_{\text {corr }}\right)$. Each experiment was carried out without MBZ inhibitor and with various concentrations of the inhibitor. The inhibition efficiency $\eta$ was calculated using equation (3):

$$
\eta=\frac{\operatorname{icorr}_{C}-\text { icorr }_{i}}{\operatorname{icorr}_{C}} \times 100,
$$

where icorr ${ }_{i}$ and icorr $_{C}$ are the corrosion current densities of mild steel coupon in the presence and absence of inhibitor, respectively.

2.4. Scanning Electron Microscopy/EDS Examination. Phenom Pro $X$ Model SEM (Phenom world, Eindhoven, Netherlands) equipped with Energy Dispersive X-ray 
spectroscopy (EDS) was employed to examine the surface morphology of the mild steel specimens after gravimetric measurements.

\section{Results and Discussions}

3.1. Gravimetric Measurements. The results of gravimetric measurement in terms of weight loss (WL), corrosion rate $(\mathrm{CR})$, percentage inhibition efficiency $(\eta)$, and surface coverage $(\Phi)$ are displayed in Table 1 while the graphical representations for the various parameters are presented in Figures 1-4. The plot of weight loss against exposure time for mild steel with and without varying concentrations of MBZ (Figure 1) showed significant decrease in weight loss upon the introduction of MBZ into the corrosive media. The rate at which weight loss occurred was reduced with increases in the concentration of the inhibitor (Figure 2). Similar trend was observed in the corrosion rates versus concentration of the inhibitor as displayed in Figure 3. While inhibition efficiency increased with increase in inhibitor concentrations as portrayed in Figure 4.

The range of weight loss $(0.10-0.78 \mathrm{~g})$, corrosion rate (0.01-0.12 mm/yr), inhibition efficiency (89.61-96.62\%), and surface coverage $(0.90-0.97)$ indicated that MBZ performed creditably well as an inhibitor of acid corrosion of mild steel. This may be attributed to effective and increased adsorption, albeit with increase in time and concentration of inhibitor molecules on the surface of the mild steel test coupons. Thus, the relatively high values of inhibition efficiency and surface coverage and lower values of corrosion rates and weight losses may be a result of the presence of several heteroatoms, such as nitrogen and oxygen atoms as well as the presence of nonbonding $\pi$-electrons in the ringed structure of MBZ [32]. These heteroatoms and free $\pi$-electrons provided the electron-rich sites through which MBZ adsorbed severally on the mild steel surface and thereby interfered positively with the anodic and/or cathodic reactions to reduce the corrosion rates of the mild steel.

It can be observed from Table 1 and Figures 1-4 that corrosion rate and weight loss values were reduced to a minimum with increase in concentration of inhibitor and exposure time. The lowest corrosion rate value of $0.01 \mathrm{~mm} / \mathrm{yr}$ corresponding to a weight loss of $0.13 \mathrm{~g}$ was achieved at $1.5 \mathrm{~g} / \mathrm{l}$ of MBZ over an immersion period of $24 \mathrm{~h}$ with a corresponding inhibition efficiency of about $96 \%$.

Because of the small differences between the inhibition efficiencies of the highest and lowest inhibitor concentrations, the experimental weight loss results were used to model and predict the performance at lower concentrations of the inhibitor $(0.05,0.1,0.2,0.3, \& 0.4 \mathrm{~g} / \mathrm{l})$. Using Response Surface Methodology (RSM), the inhibition efficiency and other corrosion properties were optimized by central composite design (CCD) tool of Design Expert software version 11.0. A quadratic design model was applied during the analysis. Inhibitor concentration and immersion time were set as the independent variables (Factors $1 \& 2$ ), while weight loss (WL), corrosion rate (CR), inhibitor efficiency (IE), and degree of surface coverage (SC) were the response variables (Responses 1 to 4 ). Thirty runs of experiments were
TABLE 1: Weight loss (g) of mebendazole in dilute $\mathrm{H}_{2} \mathrm{SO}_{4}$ at various inhibitor concentrations and exposure times.

\begin{tabular}{|c|c|c|c|c|c|}
\hline \multirow{2}{*}{$\begin{array}{l}\text { Exposure time } \\
\text { (hrs) }\end{array}$} & \multirow{2}{*}{$\begin{array}{l}\text { Corrosion } \\
\text { properties }\end{array}$} & \multicolumn{4}{|c|}{$\begin{array}{l}\text { Inhibitor concentrations } \\
(\mathrm{g} / \mathrm{l})\end{array}$} \\
\hline & & Blank & 0.5 & 1.0 & 1.5 \\
\hline \multirow{4}{*}{24} & WL (g) & 2.96 & 0.15 & 0.10 & 0.13 \\
\hline & $\mathrm{CR}(\mathrm{mm} / \mathrm{yr})$ & 2.19 & 0.11 & 0.07 & 0.01 \\
\hline & $\eta(\%)$ & - & 94.98 & 96.62 & 95.61 \\
\hline & $\Phi$ & - & 0.95 & 0.97 & 0.96 \\
\hline \multirow{4}{*}{48} & WL (g) & 5.64 & 0.22 & 0.27 & 0.30 \\
\hline & $\mathrm{CR}(\mathrm{mm} / \mathrm{yr})$ & 2.09 & 0.08 & 0.10 & 0.11 \\
\hline & $\eta(\%)$ & - & 94.68 & 96.28 & 96.10 \\
\hline & $\Phi$ & - & 0.95 & 0.96 & 0.96 \\
\hline \multirow{4}{*}{72} & WL (g) & 3.37 & 0.35 & 0.19 & 0.20 \\
\hline & $\mathrm{CR}(\mathrm{mm} / \mathrm{yr})$ & 0.83 & 0.09 & 0.05 & 0.05 \\
\hline & $\eta(\%)$ & - & 89.61 & 94.36 & 94.07 \\
\hline & $\Phi$ & - & 0.90 & 0.94 & 0.94 \\
\hline \multirow{4}{*}{96} & WL (g) & 6.07 & 0.54 & 0.36 & 0.36 \\
\hline & $\mathrm{CR}(\mathrm{mm} / \mathrm{yr})$ & 1.12 & 0.10 & 0.07 & 0.07 \\
\hline & $\eta(\%)$ & - & 91.10 & 94.07 & 94.07 \\
\hline & $\Phi$ & - & 0.91 & 0.94 & 0.94 \\
\hline \multirow{4}{*}{120} & WL (g) & 9.31 & 0.46 & 0.68 & 0.78 \\
\hline & $\mathrm{CR}(\mathrm{mm} / \mathrm{yr})$ & 1.38 & 0.07 & 0.10 & 0.12 \\
\hline & $\eta(\%)$ & - & 91.62 & 95.70 & 95.06 \\
\hline & $\Phi$ & - & 0.92 & 0.96 & 0.95 \\
\hline
\end{tabular}

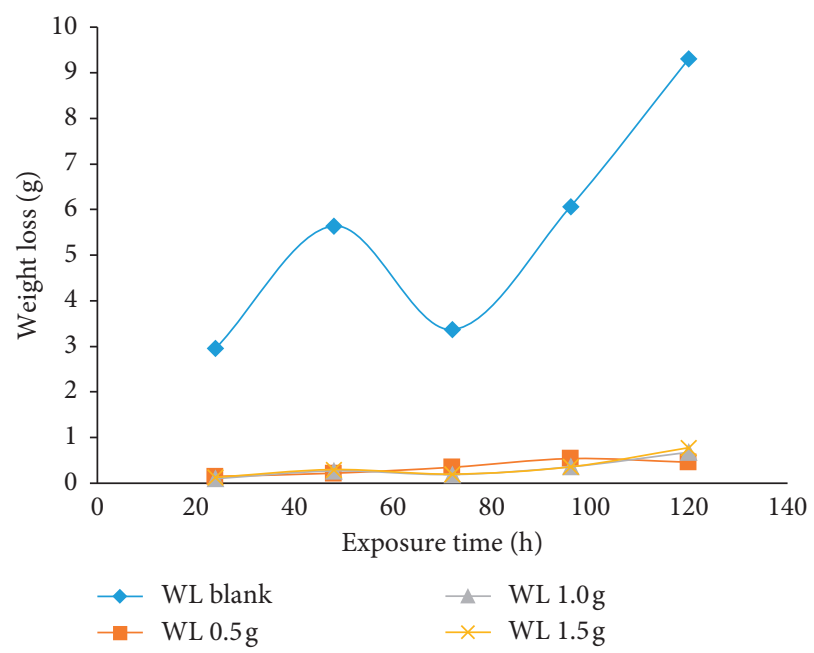

FIGURE 1: Weight loss variation of mild steel in dilute $\mathrm{H}_{2} \mathrm{SO}_{4}$ with immersion time in the presence of various concentrations of MBZ.

carried out to obtain the responses of the dependent variables/corrosion properties. Predictive model equations for inhibition efficiency (IE) of MBZ, corrosion rate (CR), and weight Loss (WL) as a function of the considered factors in terms of coded factors is given by equations (4a)-(4c)). Nonlinear, Quartic model equations sufficiently described the relationship between inhibition efficiency, corrosion rate, and the independent factors (inhibitor concentration $(B)$ and immersion time $(A)$, respectively (equations (4a) and (4b)). Conversely, a quadratic model described the relationship between weight loss (WL) and the independent factors (equation (4c)). The detailed experimental design 


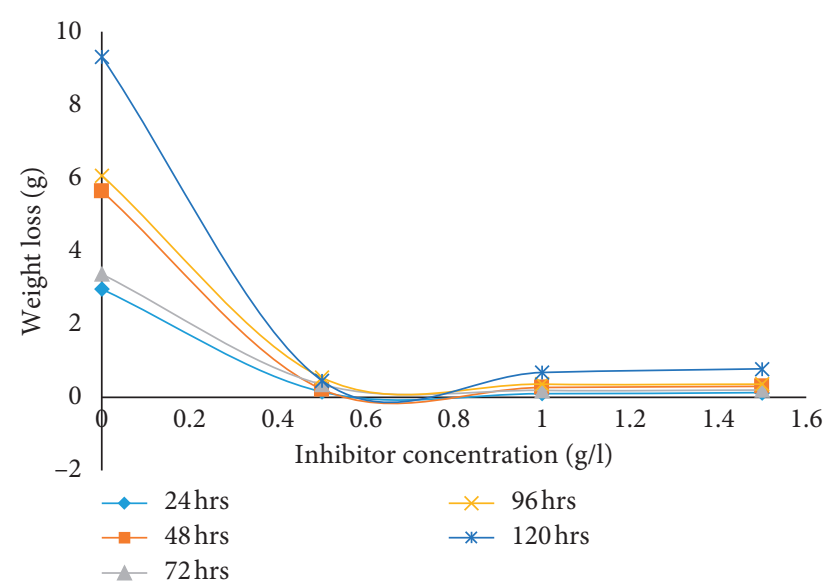

Figure 2: Weight loss (g) variation of mild steel in dilute $\mathrm{H}_{2} \mathrm{SO}_{4}$ with inhibitor concentration $(\mathrm{g} / \mathrm{l})$.

with the graphical plots, mathematical modelling, optimization, analysis of variance (ANOVA), other statistical evaluations, etc. are reported in $[33,34]$. The following modelled results (Table 2) experimentally validated were obtained, showing the trend of increase in inhibition efficiency with increasing concentrations of the inhibitor. This trend is graphically displayed in Figure 5.

$$
\begin{aligned}
\mathrm{IE}(\%)= & +92.61-2.32 A-18.34 B+1.63 A B+2.23 A^{2} \\
+ & 33.09 B^{2}-1.63 A^{2} B+0.6540 A B^{2}+1.13 A^{3} \\
+ & 66.52 B^{3}-1.06 A^{2} B^{2}-0.2587 A^{3} B-2.31 A B^{3} \\
- & 1.42 A^{4}-78.02 B^{4} \\
\mathrm{CR}\left(\frac{\mathrm{mm}}{\mathrm{yr}}\right)= & +0.0436-0.0772 A+0.4081 B+0.0875 A B \\
& +0.5997 A^{2}-0.6817 B^{2}-0.2054 A^{2} B \\
& -0.2842 A B^{2}+0.1402 A^{3}-1.03 B^{3} \\
& +0.3540 A^{2} B^{2}-0.2537 A^{3} B+0.3870 A B^{3} \\
& -0.5706 A^{4}+1.20 B^{4},
\end{aligned}
$$

$\mathrm{WL}(\mathrm{g})=-0.36014+0.616333 A-1.87714 B-0.863571 A B$

$$
+0.391905 A^{2}+2.84754 B^{2} \text {. }
$$

Figure 1 shows that the corrosion rate for the blank specimen initially increased rapidly; however, after $50 \mathrm{~h}$ of exposure, the corrosion rate decreased probably as a result of the passivation of the specimens by adherent corrosion products which were not readily removable from the surface of the specimens during cleaning $[1,35]$. At $70 \mathrm{~h}$ immersion time, the rate of corrosion continued its upward surge as flaws within the adherent corrosion products were

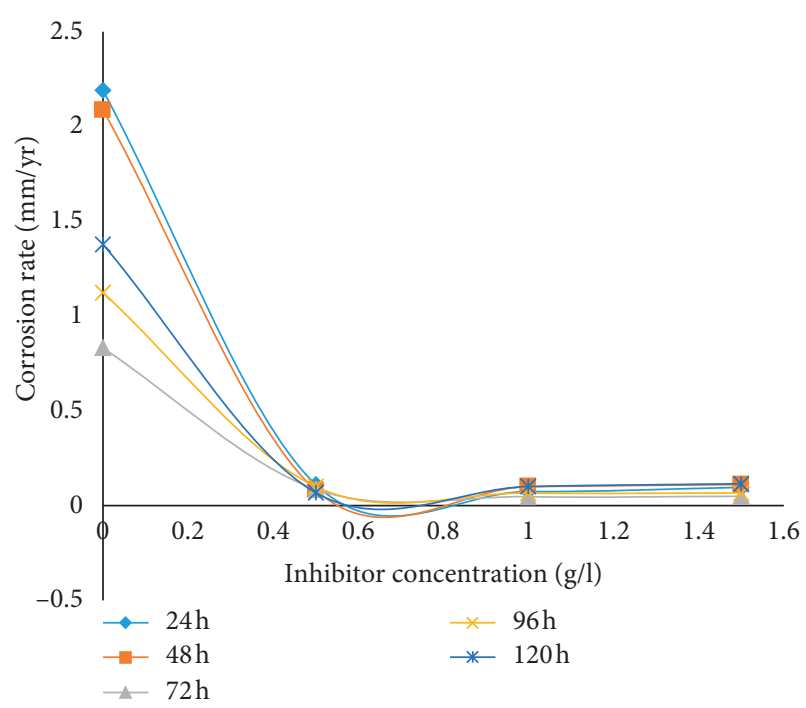

Figure 3: Corrosion rate $(\mathrm{mm} / \mathrm{yr})$ of mild steel in dilute $\mathrm{H}_{2} \mathrm{SO}_{4}$ with variation in inhibitor concentration $(\mathrm{g} / \mathrm{l})$ at various immersion times.

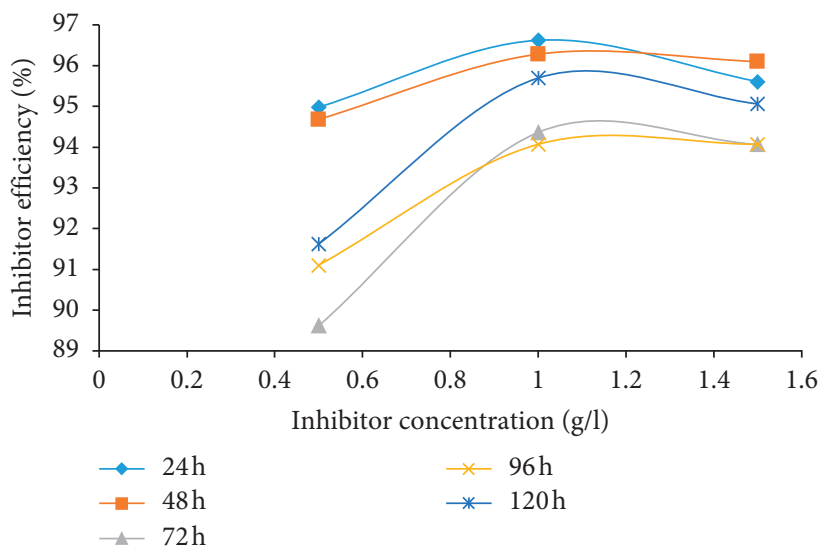

FIGURE 4: Inhibitor efficiency (\%) versus concentration of MBZ for mild steel in $1.5 \mathrm{M} \mathrm{H}_{2} \mathrm{SO}_{4}$.

undermined to reveal the substrate to further corrosion activities in the acidic environment. With the addition of $\mathrm{MBZ}$ at various concentrations to the corroding systems, the corrosion rates were reduced to their barest minimum (Figure 2).

As displayed in Figure 2, MBZ was able maintain the low weight loss of the mild steel at a concentration of $0.5 \mathrm{~g}$ for exposure times ranging from 24 to $120 \mathrm{~h}$. For $24 \mathrm{~h}$ exposure, the reduction in weight loss of mild steel while corroding freely was from $3 \mathrm{~g}$ to about $0.1 \mathrm{~g}$ on adding $0.5 \mathrm{~g} / \mathrm{l}$ of the inhibitor to the corroding system. This massive reduction in weight loss was replicated for all concentrations of MBZ employed in this investigation. The reduction in the weight loss of the mild steel in the acid solution containing the MBZ can be attributed to the formation of a protective layer by the inhibitor molecules around the mild steel. It also points to the presence of heterocyclic nitrogen and lone pair of electron in the structure of the inhibitor that are readily 
TABLe 2: Predicted weight loss (g) results of mild steel in the presence of small quantities of MBZ in dilute $\mathrm{H}_{2} \mathrm{SO}_{4}$.

\begin{tabular}{|c|c|c|c|c|}
\hline Exposure time (h) & Inh. conc. $(\mathrm{g} / \mathrm{l})$ & Weight loss (g) & Corrosion rate $(\mathrm{mm} / \mathrm{yr})$ & Inhibition efficiency (\%) \\
\hline 24 & 0.05 & 3.01 & 1.89 & 16.86 \\
\hline 48 & 0.05 & 3.44 & 1.58 & 16.60 \\
\hline 72 & 0.05 & 4.07 & 1.13 & 15.41 \\
\hline 96 & 0.05 & 4.89 & 1.28 & 15.32 \\
\hline 120 & 0.05 & 5.90 & 1.95 & 16.27 \\
\hline 24 & 0.1 & 2.76 & 1.60 & 31.32 \\
\hline 48 & 0.1 & 3.17 & 1.34 & 30.93 \\
\hline 72 & 0.1 & 3.78 & 0.93 & 29.61 \\
\hline 96 & 0.1 & 4.58 & 1.11 & 29.42 \\
\hline 120 & 0.1 & 5.58 & 1.77 & 30.26 \\
\hline 24 & 0.2 & 2.28 & 1.11 & 55.04 \\
\hline 48 & 0.2 & 2.65 & 0.94 & 54.42 \\
\hline 72 & 0.2 & 3.23 & 0.60 & 52.91 \\
\hline 96 & 0.2 & 3.99 & 0.82 & 52.52 \\
\hline 120 & 0.2 & 4.96 & 1.47 & 53.16 \\
\hline 24 & 0.3 & 1.83 & 0.73 & 72.71 \\
\hline 48 & 0.3 & 2.17 & 0.65 & 71.92 \\
\hline 72 & 0.3 & 2.71 & 0.37 & 70.24 \\
\hline 96 & 0.3 & 3.45 & 0.62 & 69.70 \\
\hline 120 & 0.3 & 4.37 & 1.26 & 70.17 \\
\hline 24 & 0.4 & 1.42 & 0.45 & 85.31 \\
\hline 48 & 0.4 & 1.73 & 0.43 & 84.39 \\
\hline 72 & 0.4 & 2.23 & 0.21 & 82.60 \\
\hline 96 & 0.4 & 2.93 & 0.49 & 81.93 \\
\hline 120 & 0.4 & 3.83 & 1.11 & 82.26 \\
\hline
\end{tabular}

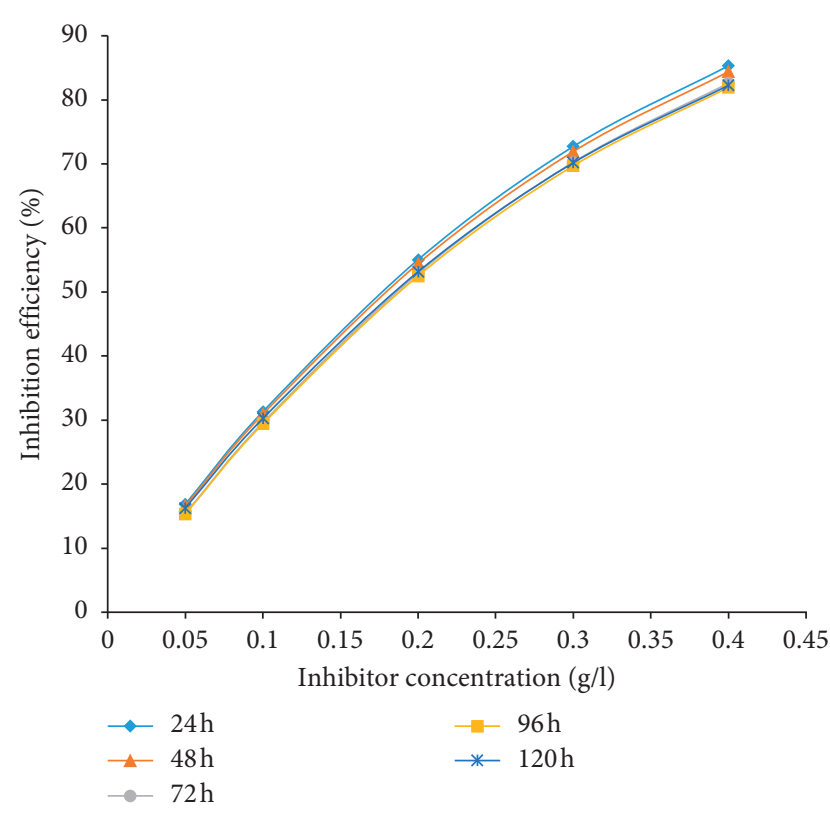

FIgURE 5: Plot of modelled inhibition efficiency (\%) versus concentration of MBZ for mild steel in dilute $\mathrm{H}_{2} \mathrm{SO}_{4}$.

available for adsorption on the surface of the mild steel $[34,36]$.

From Figure 3, it can be observed that the graphs followed a similar pattern to those of the gravimetric curves in Figure 2. This is expected because weight loss is a reflection of the magnitude of corrosion of the mild steel. Examination of the figure revealed that the corrosion rate of mild steel in dilute $\mathrm{H}_{2} \mathrm{SO}_{4}$ solution was reduced upon the introduction of MBZ into the corrosive medium. The extent of reduction in corrosion rate is seen to proceed gradually with further increase in the concentration of the inhibitor beyond $0.5 \mathrm{~g} / \mathrm{l}$, for all the immersion durations. This reduction in weight loss obtained in Figure 2 leads to a corresponding decrease in corrosion rates due to the corrosion retarding action of the studied inhibitor.

From Figure 4, the inhibition efficiency was high initially for all concentrations; however, a general slight decline was observed with exposure time as the inhibiting species adhered and probably desorbed from the metal substrate in competition/crowding with increasing exposure time $[19,37-39]$. Considering the influence of the inhibitor concentration on the inhibition efficiency, a gradual increase could be noticed from 0.5 to $1.5 \mathrm{~g} / \mathrm{l}$.

In order to justify the general increase in the efficiency of MBZ at low concentrations, a model (equation (4a)) was developed and used to predict the inhibition efficiencies for concentrations of $0.05 \mathrm{~g} / \mathrm{l}$ to $0.45 \mathrm{~g} / \mathrm{l}$. The predicted results presented in Table 2 were used to plot Figure 5. The modelled and predicted results of inhibition efficiencies for lower concentrations of the inhibitor succinctly show a definite trend of inhibition efficiency increasing with inhibitor concentration up to $0.5 \mathrm{~g} / \mathrm{l}$. However, between $0.5 \mathrm{~g} /$ 1 and $1.5 \mathrm{~g} / \mathrm{l}$, a slight variation was observed in the inhibition efficiencies as shown earlier in Figure 4. Thus, the inhibitor is predictably very effective at lower concentrations. 


\subsection{Electrochemical Measurements}

3.2.1. Potentiodynamic Polarization Measurements/Tafel Extrapolation. The main purpose of polarization measurements was to find out the influence of the introduction of various concentrations of $\mathrm{MBZ}$ on the dissolution rate of mild steel as well as the corresponding cathodic reduction rate of hydrogen ion during the corrosion process. The polarization plots obtained for the corrosion of mild steel in dilute $\mathrm{H}_{2} \mathrm{SO}_{4}$ in the absence and presence of inhibitor at various concentrations are shown in Figures 6 and 7. The polarization curves indicated that the introduction of $\mathrm{MBZ}$ into $\mathrm{H}_{2} \mathrm{SO}_{4}$ had moderately pronounced effects on both the anodic and cathodic reactions. The Tafel extrapolation of the polarization curves gave the potentiodynamic parameters as described in Tables 3 and 4. From Tables 3 and 4, it could be observed that the introduction of MBZ shifted the $E_{\text {corr }}$ significantly in the positive direction indicative of an anodic inhibition. A corrosion inhibitor may act as a cathodic, anodic, or mixed type, depending on the level of the displacement of the $E_{\text {corr }}$. If the displacement in $E_{\text {corr }}$ is greater than $85 \mathrm{mV}$ with reference to $E_{\text {corr }}$, the inhibitor may act as a cathodic or anodic type, and if the displacement is less than $85 \mathrm{mV}$, the inhibitor may be classified as a mixed type $[12,40]$. It could be deduced from the polarization results that the MBZ behaved as mixed-type inhibitor. The displacement of $E_{\text {corr }}$ observed in this study is less than $85 \mathrm{mV}$ both at $30^{\circ} \mathrm{C}$ and $60^{\circ} \mathrm{C}$.

The results of maximum corrosion inhibition efficiencies computed from gravimetric and the polarization parameters at both $30^{\circ} \mathrm{C}$ and $60^{\circ} \mathrm{C}$ were generally similar in numerical values which suggested that both methods complemented each other. The MBZ inhibitor protected the mild steel from corrosion in the aggressive solution with maximum inhibition efficiencies of $84.93 \%$ for $1.5 \mathrm{~g} \mathrm{MBZ}$ in dilute $\mathrm{H}_{2} \mathrm{SO}_{4}$ at elevated temperature, whereas $99.05 \%$ was observed for $1.0 \mathrm{~g}$ $\mathrm{MBZ}$ at room temperature.

3.2.2. Effect of Temperature and Mechanism of Adsorption. The rate of corrosion as expected increases with increase in temperature for it is generally known that for every $10^{\circ} \mathrm{C}$ rise in temperature, the rate of any reaction doubles. However, the efficiency of $\mathrm{MBZ}$ at $60^{\circ} \mathrm{C}$ declined to between about 35 to $85 \%$ for inhibitor concentrations of $0.5 \mathrm{~g}$ and $1.5 \mathrm{~g}$, respectively, as against 96 and $97 \%$ for similar concentrations at room temperature. This observation can be ascribed to the rapid etching and desorption of inhibitor molecules from the surface of the substrate [2, 41-44], suggesting initial physical adsorption [45]. This view is corroborated by the findings of [19] and by [27]. Alternatively, an increase in inhibition efficiency and decrease in corrosion rate with rise in temperature is indicative of chemisorption mechanism. The decreased inhibition efficiencies and higher corrosion rates obtained for the test specimens at elevated temperature as suggested by other researchers $[19,22]$ were an indication that the critical concentration of anions required for the protection of mild steel in the corrosive media increases as the temperature increased.

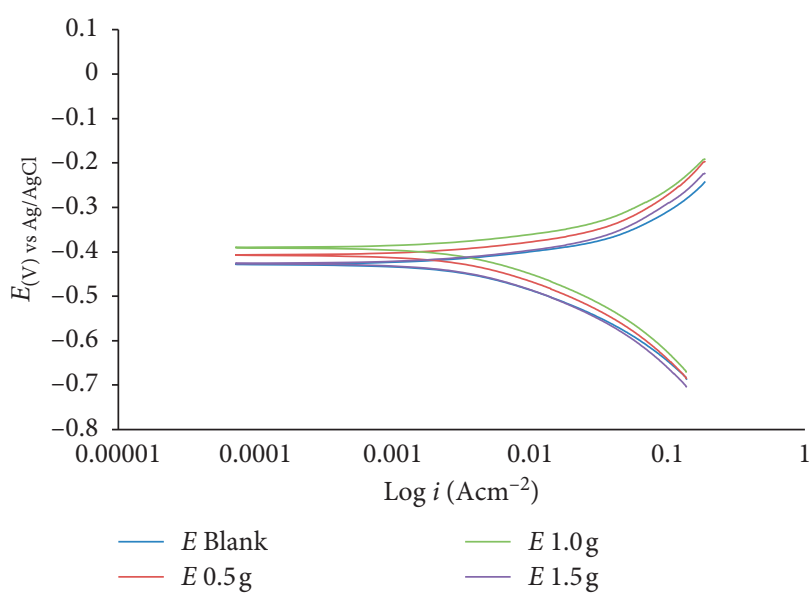

FIgURE 6: Potentiodynamic polarization curve of mild steel in dilute $\mathrm{H}_{2} \mathrm{SO}_{4}$ in the absence and presence of $\mathrm{MBZ}$ at $30^{\circ} \mathrm{C}$.

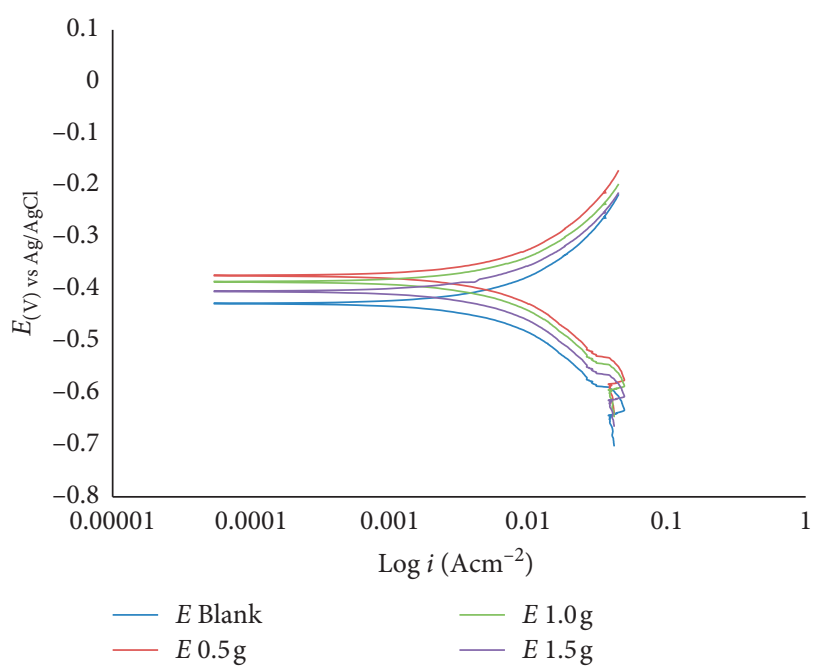

Figure 7: Potentiodynamic polarization curve of mild steel in dilute $\mathrm{H}_{2} \mathrm{SO}_{4}$ in the absence and presence of the corrosion inhibitor at $60^{\circ} \mathrm{C}$.

In order to further obtain information about the mechanism of inhibition, the data obtained in the electrochemical (potentiodynamic polarization) investigation were further analysed using adsorption isotherms as described by [30]. Frumkin, Temkin, Freundlich, and Langmuir isotherms and their variations are the most frequently used isotherms to evaluate the mechanism of inhibition of corrosion rates. From the various plots, the Langmuir adsorption isotherm provided the best and most suitable description of the behaviour of MBZ with a linear graph and near unity slopes and correlation coefficient of 1.02 and 0.9993 , respectively. The correlation coefficient $\left(R^{2}\right)$ value (0.3393) for the reaction at $60^{\circ} \mathrm{C}$ deviated significantly from unity, which also supported the deduction that the critical concentrations of anions required for the protection of metals in corrosive media increased as the temperature was increased. There was a slight slope deviation and correlation 
Table 3: Potentiodynamic polarization parameters at $30^{\circ} \mathrm{C}$.

\begin{tabular}{lcccccc}
\hline Inhibitor conc. $(\mathrm{g})$ & $I_{\text {corr }}(\mu \mathrm{A})$ & $E_{\text {corr }}(\mathrm{mV})$ & Corrosion rate $(\mathrm{mm} / \mathrm{yr})$ & Inhibitor efficiency $(\%)$ & Cathodic beta $(\mathrm{mV})$ & Anodic beta $(\mathrm{mV})$ \\
\hline 0.0 & $-6.58 \mathrm{~mA}$ & -429.75 & 48.61 & - & 182.00 & 104.32 \\
0.5 & -286.02 & -409.55 & 2.11 & 95.65 & 136.93 & 84.26 \\
1.0 & -62.22 & -407.58 & 0.46 & 99.05 & 110.80 & 57.01 \\
1.5 & -182.34 & -442.46 & 1.35 & 97.23 & 99.91 & 134.25 \\
\hline
\end{tabular}

TABLE 4: Potentiodynamic polarization parameters at $60^{\circ} \mathrm{C}$.

\begin{tabular}{lcccccc}
\hline Inhibitor conc. $(\mathrm{g})$ & $I_{\text {corr }}(\mathrm{mA})$ & $E_{\text {corr }}(\mathrm{mV})$ & Corrosion rate $(\mathrm{mm} / \mathrm{yr})$ & Inhibitor efficiency $(\%)$ & Cathodic beta $(\mathrm{mV})$ & Anodic beta $(\mathrm{mV})$ \\
\hline 0.0 & -48.08 & -427.50 & 355.32 & - & $1.47 \mathrm{~V}$ & 971.45 \\
0.5 & -31.23 & -384.01 & 230.81 & 35.04 & 469.28 & 421.72 \\
1.0 & -8.82 & -385.40 & 65.22 & 81.65 & 224.48 & 108.94 \\
1.5 & -7.24 & -396.94 & 53.54 & 84.93 & 222.56 & 113.70 \\
\hline
\end{tabular}

coefficients of the Langmuir plot from unity, which may be attributed to the interactions among adsorbed species on the metal surface and changes in the adsorption heat with increasing surface coverage $[23,24,40]$. The adsorption isotherm, Figure 8, was plotted for MBZ using the linear form of the Langmuir adsorption isotherm shown in equation (5):

$$
\frac{C_{\text {inh }}}{\theta}=\frac{1}{K_{\text {ads }}}+C_{\text {inh }} \text {, }
$$

where $\theta, K_{\text {ads }}$, and $C_{\text {inh }}$ indicated the degree of surface coverage, adsorption/desorption process equilibrium constant, and inhibitor concentration, respectively.

Employing equation (6), the change in adsorption Gibb's free energy $\left(\Delta G_{\mathrm{ads}}^{\circ}\right)$ was obtained:

$$
\Delta G_{\mathrm{ads}}^{\circ}=-R T \ln \left(55.5 K_{\mathrm{ads}}\right),
$$

where $R$ is gas constant $\left(8.314 \mathrm{~kJ}^{-1} \cdot \mathrm{mol}^{-1}\right), 55.5$ is a constant that depicts the molar concentration $\left(\mathrm{mol} \cdot \mathrm{L}^{-1}\right)$ of water in the solution, $K_{\mathrm{ads}}$ is the adsorption process equilibrium constant for the adsorption process, and $T$ is the absolute temperature. Table 5 presents the computed values of $K_{\text {ads }}$ and $\Delta G_{\text {ads }}^{\circ}$ for the inhibitor at various temperatures and inhibitor concentrations. As a result of the effective and spontaneous adsorption of the MBZ molecules to the surface of mild steel in $\mathrm{H}_{2} \mathrm{SO}_{4}, K_{\text {ads }}$ values were high and negative values were obtained for $\Delta G_{\text {ads }}^{\circ}$ Through the magnitude of $\Delta G_{\text {ads }}^{\circ}$, the adsorptive nature was determined. However, for physical adsorption mechanism, values of about $-20 \mathrm{~kJ} \cdot \mathrm{mol}^{-1}$ and less are associated, while values of $-40 \mathrm{~kJ} \cdot \mathrm{mol}^{-1}$ and above are usually considered to be chemisorption $[13,24,28,30]$. The results in Table 5 revealed that the computed values of $\Delta G_{\text {ads }}^{\circ}$ for the inhibitor ranged between -17.76 to $-21.48 \mathrm{~kJ} \cdot \mathrm{mol}^{-1}$ and -11.33 to $-15.25 \mathrm{~kJ} \cdot \mathrm{mol}^{-1}$ at $303 \mathrm{~K}$ and $333 \mathrm{~K}$, respectively. This implied that the adsorption process of the inhibitor was by physiosorption. The values obtained for $\Delta G_{\text {ads }}^{\circ}$ and $K_{\text {ads }}$ were observed to decrease with increase in temperature and inhibitor concentration which is corroborated by the findings of [31].

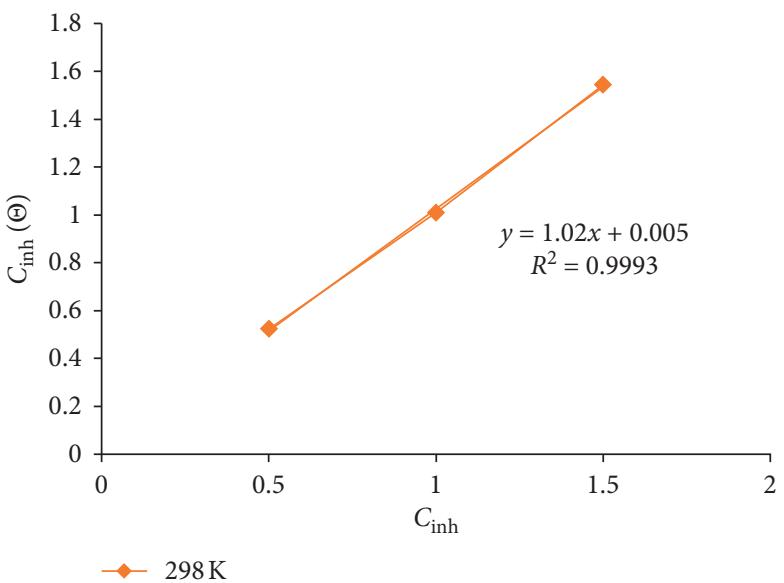

FIGURE 8: Langmuir adsorption isotherm for the adsorption of MBZ on mild steel in dilute $\mathrm{H}_{2} \mathrm{SO}_{4}$.

3.3. Surface Morphology. From the scanning electron microscopy (SEM) images shown in Figure 9(a), a number of wide and deep corrosion pits, marked with square box, can be observed on the mild steel surface besfore the introduction of MBZ. Sulphuric acid at low pH is known to cause aggravated damages to mild steel; however, in the presence of MBZ inhibitor, there was a significant protection of the specimen leading to a relatively smooth morphology. Figures 9(b) and 9(d) show the EDX spectra, while Figures 9(a) and 9(c) also have the tabulated EDX results showing the elemental composition of the mild steel coupon.

The SEM micrograph displayed in Figure 9(c) revealed some corrosion products, marked $\mathrm{Y}$, which are probable stifled pitting corrosion initiated regions, in the presence of MBZ inhibitor.

The metallic ions indicated in the EDX analyses in Figures 9(a) and 9(c) and those indicated in the spectra of Figures 9(b) and 9(d) are mostly derived from the mild steel specimen, whereas sulphur, sodium, and some other species like phosphorus may have been derived from the sulphuric acid employed in this investigation. 
TABLE 5: Gibbs free energy, surface coverage, and equilibrium constant of adsorption for $\mathrm{MBZ}$ inhibitor in $1.5 \mathrm{M} \mathrm{H}_{2} \mathrm{SO}_{4}$.

\begin{tabular}{lllll}
\hline Temperature $(\mathrm{K})$ & Inhibitor conc. $(\mathrm{g} / \mathrm{l})$ & $\Delta G_{\mathrm{ads}}^{\circ}\left(\mathrm{kJ} \cdot \mathrm{mol}^{-1}\right)$ & $K_{\text {ads }}\left(\mathrm{mol}^{-1}\right)$ & Surface coverage \\
\hline \multirow{3}{*}{303} & 0.5 & -19.33 & 44.00 & 0.96 \\
& 1.0 & -21.48 & 104.71 & 0.99 \\
333 & 1.5 & -17.76 & 23.38 & 0.97 \\
& 0.5 & -11.33 & 1.08 & 0.35 \\
& 1.0 & -15.25 & 4.45 & 0.82 \\
\\
\hline
\end{tabular}

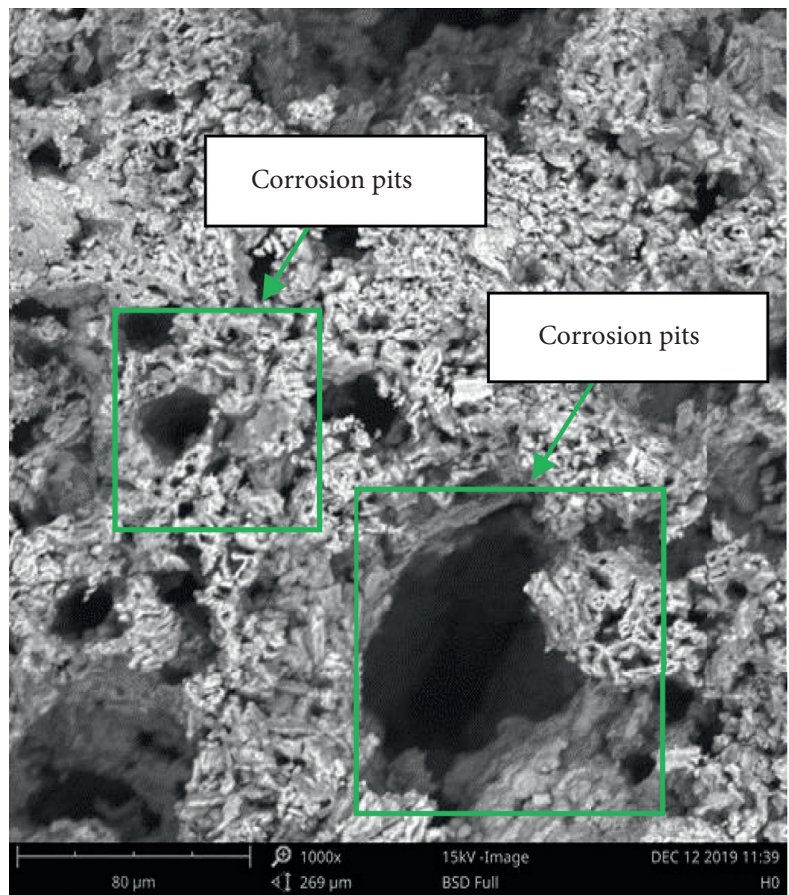

\begin{tabular}{lcc}
\hline $\begin{array}{l}\text { Element } \\
\text { symbol }\end{array}$ & $\begin{array}{c}\text { Atomic } \\
\text { conc. }\end{array}$ & $\begin{array}{c}\text { Weight } \\
\text { conc. }\end{array}$ \\
\hline $\mathrm{Fe}$ & 81.44 & 83.26 \\
$\mathrm{Mn}$ & 3.63 & 3.65 \\
$\mathrm{Cr}$ & 2.12 & 2.02 \\
$\mathrm{Cd}$ & 0.95 & 1.96 \\
$\mathrm{Sn}$ & 0.88 & 1.92 \\
$\mathrm{~S}$ & 3.01 & 1.76 \\
$\mathrm{Ag}$ & 0.67 & 1.32 \\
$\mathrm{Ti}$ & 1.08 & 0.95 \\
$\mathrm{~V}$ & 0.82 & 0.77 \\
$\mathrm{P}$ & 1.06 & 0.60 \\
$\mathrm{C}$ & 1.83 & 0.40 \\
$\mathrm{Si}$ & 0.60 & 0.31 \\
$\mathrm{~K}$ & 0.41 & 0.29 \\
$\mathrm{Ca}$ & 0.39 & 0.29 \\
$\mathrm{Al}$ & 0.48 & 0.24 \\
$\mathrm{Na}$ & 0.41 & 0.17 \\
$\mathrm{Mg}$ & 0.23 & 0.10 \\
\hline
\end{tabular}

(a)

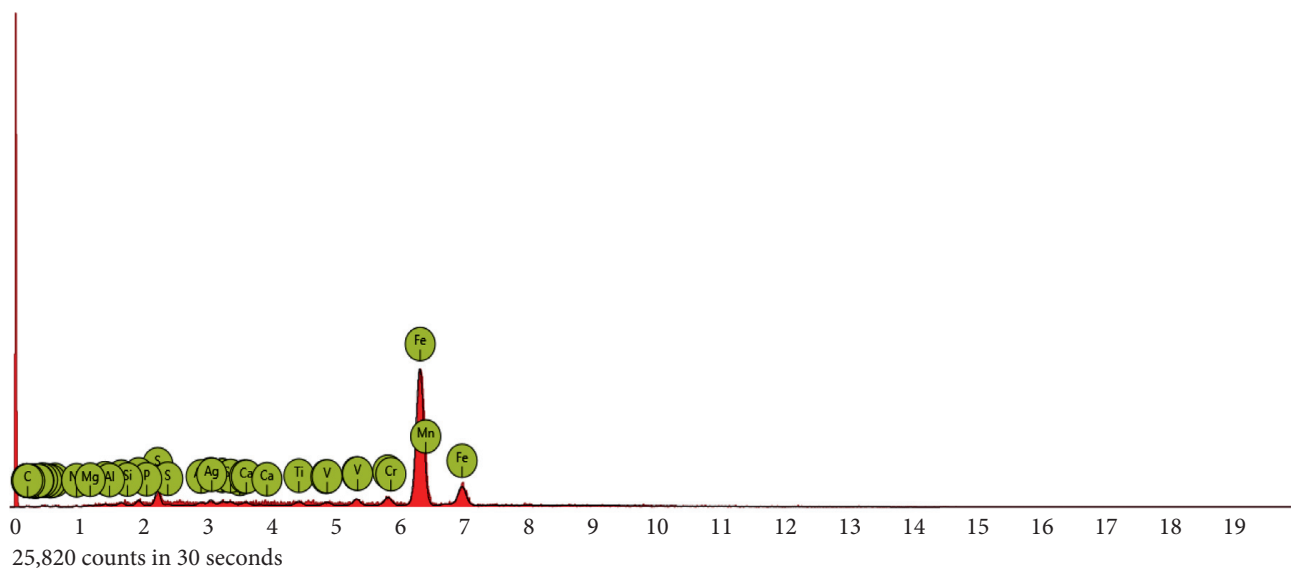

(b)

FIgURE 9: Continued. 


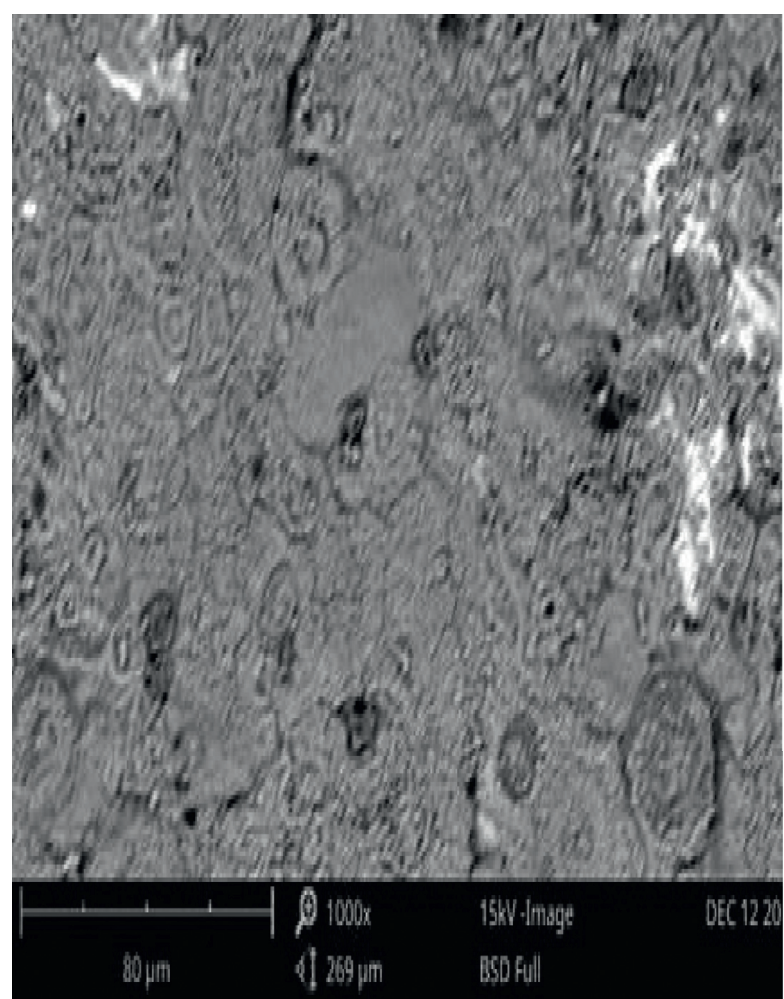

(c)

\begin{tabular}{lcc}
\hline $\begin{array}{l}\text { Element } \\
\text { symbol }\end{array}$ & $\begin{array}{c}\text { At. } \\
\text { conc. }\end{array}$ & $\begin{array}{c}\text { Wt. } \\
\text { conc. }\end{array}$ \\
\hline $\mathrm{Fe}$ & 81.34 & 83.90 \\
$\mathrm{Mn}$ & 2.57 & 2.61 \\
$\mathrm{Cd}$ & 1.10 & 2.28 \\
$\mathrm{~S}$ & 3.76 & 2.23 \\
$\mathrm{Ag}$ & 0.97 & 1.93 \\
$\mathrm{Sn}$ & 0.78 & 1.71 \\
$\mathrm{Ti}$ & 0.89 & 0.79 \\
$\mathrm{Ca}$ & 0.91 & 0.67 \\
$\mathrm{Si}$ & 1.30 & 0.67 \\
$\mathrm{Cr}$ & 0.68 & 0.65 \\
$\mathrm{~V}$ & 0.63 & 0.59 \\
$\mathrm{C}$ & 2.53 & 0.56 \\
$\mathrm{P}$ & 0.94 & 0.54 \\
$\mathrm{Al}$ & 0.76 & 0.38 \\
$\mathrm{~K}$ & 0.40 & 0.29 \\
$\mathrm{Mg}$ & 0.23 & 0.10 \\
$\mathrm{Na}$ & 0.22 & 0.09 \\
\hline & &
\end{tabular}

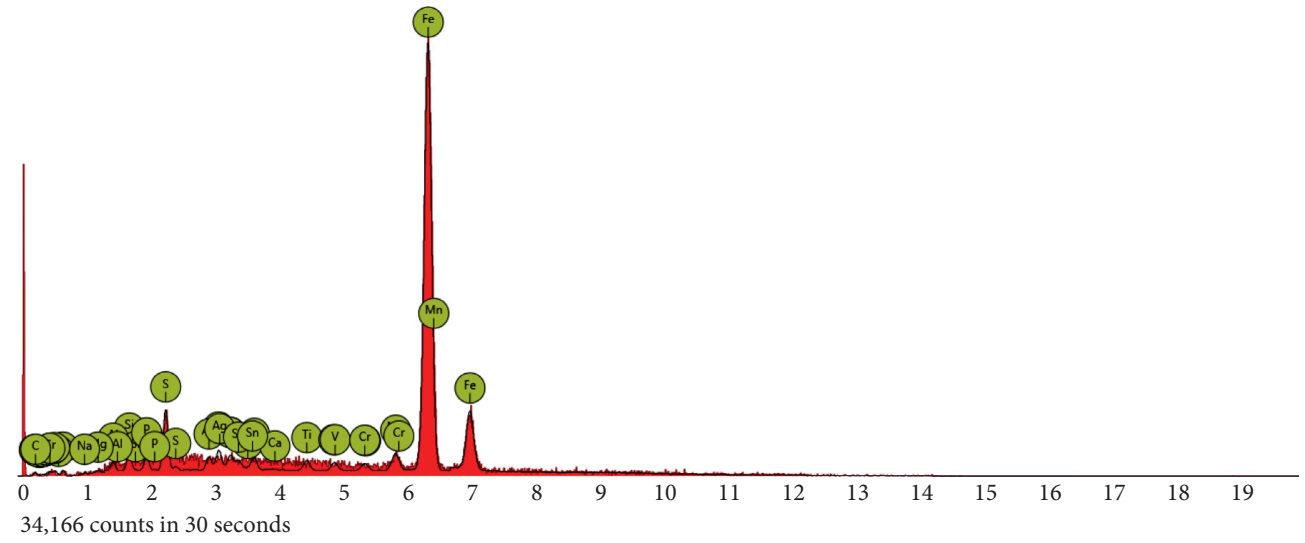

(d)

FIGURE 9: SEM micrograph of mild steel coupon with the EDX analysis data after 4 days immersion in $\mathrm{H}_{2} \mathrm{SO}_{4}$ without $\mathrm{MBZ}_{\text {inhibitor and }}$ containing $1.5 \mathrm{~g}$ of MBZ. EDX spectra of mild steel coupon after 4 days immersion in a $1.5 \mathrm{M} \mathrm{H}_{2} \mathrm{SO}_{4}$ solution containing $1.5 \mathrm{~g}$ of $\mathrm{MBZ}$ inhibitor.

\section{Conclusions}

The heteroatoms being the active centre in the inhibitor moiety effectively reduced the corrosion rate of mild steel in the dilute sulphuric acid employed in this investigation. Tafel extrapolation from the polarization curves showed that MBZ performed as a mixed inhibitor such that it reduced the rates of both the anodic and cathodic reactions. The percentage inhibition on the corrosion rate of mild steel in dilute sulphuric acid increased with increase in the concentration of MBZ, whereas it decreased with increase in the temperature regimes employed in this study, which is indicative of physiosorption mechanism. From thermodynamics considerations, the adsorption process followed the Langmuir adsorption isotherm. The surface morphologies, as revealed from SEM before and after addition of MBZ as corrosion inhibitor, support and give credence to the gravimetric and electrochemical tests.

\section{Data Availability}

The data used to support the findings of this study are included within the article. 


\section{Conflicts of Interest}

The authors declare that they have no conflicts of interest.

\section{Acknowledgments}

The authors acknowledge the financial support provided by the Tertiary Education Trust Fund (TETFUND), Nigeria through the Institution Based Research (IBR) Interventions for the research. A. A. A. appreciates Landmark University Centre for Research, Innovation and Development (LUCRID) for their support.

\section{References}

[1] M. Oki, "Corrosion inhibitors and their applications in the petroleum industry," in Corrosion and Materials in the Oil and Gas Industries, R. Javaherdashti, C. Nwaoha, and H. Tan, Eds., CRC Press, Boca Raton, FL, USA, pp. 415-430, 2013.

[2] M. Oki, K. Oki, J. Otaigbe, and S. Otikor, "Corrosion inhibition of aluminium in $\mathrm{HCl}$ by amine modified epoxy resin," Journal of Materials, vol. 2013, Article ID 479728, 5 pages, 2013.

[3] N. O. Eddy, S. A. Odoemelam, and P. Ekwumemgbo, "Inhibition of the corrosion of mild steel in $\mathrm{H}_{2} \mathrm{SO}_{4}$ by penicillin G," Scientific Research and Essays, vol. 4, pp. 33-38, 2009.

[4] C. A. Loto, R. T. Loto, and O. O. Joseph, "Effect of benzamide on the corrosion inhibition of mild steel in sulphuric acid," South African Journal of Chemistry, vol. 70, pp. 38-43, 2017.

[5] S. O. Pehkonen and S. Yuan, "Tailored thin coatings for corrosion inhibition using a molecular approach," in Interface Science Technology, S. O. Pehkonen and S. Yuan, Eds., pp. 1-11, Elsevier, Amsterdam, Netherlands, 23rd edition, 2018.

[6] R. T. Loto, C. A. Loto, O. Joseph, and G. Olanrewaju, “Adsorption and corrosion inhibition properties of thiocarbanilide on the electrochemical behavior of high carbon steel in dilute acid solutions," Results in Physics, vol. 6, pp. 305-314, 2016.

[7] B. U. Odoni, F. O. Edoziuno, and N. C. Chukwurah, "Corrosion inhibition potential of methyl-5-benzoyl-2-benzimidazole carbamate (mebendazole) for mild steel in $1.0 \mathrm{~m}$ sulphuric acid," International Journal of Engineering Innovations, vol. 1, pp. 190-194, 2017.

[8] M. Finšgar and J. Jackson, "Application of corrosion inhibitors for steels in acidic media for the oil and gas industry: a review," Corrosion Science, vol. 86, pp. 17-41, 2014.

[9] G. Gece, "Drugs: a review of promising novel corrosion inhibitors," Corrosion Science, vol. 53, no. 12, pp. 3873-3898, 2011.

[10] T. H. Ibrahim and M. A. Zour, "Corrosion inhibition of mild steel using fig leaves extract in hydrochloric acid solution," International Journal of Electrochemical Science, vol. 6, pp. 6442-6455, 2011.

[11] O. D. Onukwuli and M. Omotioma, "Study of bitter leaves extract as inhibitive agent in $\mathrm{HCl}$ medium for the treatment of mild steel through pickling," Portugaliae Electrochimica Acta, vol. 37, no. 2, pp. 115-121, 2019.

[12] A. Singh, E. E. Ebenso, and M. A. Quraishi, "Corrosion inhibition of carbon steel in $\mathrm{HCl}$ solution by some plant extracts," International Journal of Corrosion, vol. 2012, Article ID 897430, 20 pages, 2012.
[13] Y. Tang, F. Zhang, S. Hu, Z. Cao, Z. Wu, and W. Jing, "Novel benzimidazole derivatives as corrosion inhibitors of mild steel in the acidic media. Part I: gravimetric, electrochemical, SEM and XPS studies," Corrosion Science, vol. 74, pp. 271-282, 2013.

[14] C. A. Loto and R. T. Loto, "Corrosion inhibition effect of Allium Cepa extracts on mild steel in $\mathrm{H}_{2} \mathrm{SO}_{4}$," Der Pharma Chemistry, vol. 8, pp. 63-73, 2016.

[15] O. Olawale, A. A. Adediran, S. I. Talabi, G. C. Nwokocha, and A. O. Ameh, "Inhibitory action of Vernonia amygdalina extract (VAE) on the corrosion of carbon steel in acidic medium," Journal of Electrochemical Science and Engineering, vol. 7, no. 3, pp. 145-152, 2017.

[16] M. Krishnan, H. Subramanian, H.-U. Dahms et al., "Biogenic corrosion inhibitor on mild steel protection in concentrated $\mathrm{HCl}$ medium," Scientific Reports, vol. 8, no. 1, pp. 1-16, 2018.

[17] S. Karthikeyan, "Drugs/antibiotics as potential corrosion inhibitors for metals-a review," International Journal of ChemTech Research, vol. 9, pp. 251-259, 2016.

[18] J. T. Nwabanne and V. N. Okafor, "Adsorption and thermodynamics study of the inhibition of corrosion of mild steel in $\mathrm{H}_{2} \mathrm{SO}_{4}$ medium using Vernonia amygdalina," Journal of Minerals and Materials Characterization and Engineering, vol. 11, no. 9, pp. 885-890, 2012.

[19] T. Peme, L. Olasunkanmi, I. Bahadur, A. Adekunle, M. Kabanda, and E. Ebenso, "Adsorption and corrosion inhibition studies of some selected dyes as corrosion inhibitors for mild steel in acidic medium: gravimetric, electrochemical, quantum chemical studies and synergistic effect with iodide ions," Molecules, vol. 20, no. 9, pp. 16004-16029, 2015.

[20] E. E. Oguzie, Y. Li, and F. H. Wang, "Corrosion inhibition and adsorption behavior of methionine on mild steel in sulfuric acid and synergistic effect of iodide ion," Journal of Colloid and Interface Science, vol. 310, no. 1, pp. 90-98, 2007.

[21] M. Mashuga, L. Olasunkanmi, A. Adekunle, S. Yesudass, M. Kabanda, and E. Ebenso, "Adsorption, thermodynamic and quantum chemical studies of 1-hexyl-3-methylimidazolium based ionic liquids as corrosion inhibitors for mild steel in $\mathrm{HCl}$," Materials, vol. 8, no. 6, pp. 3607-3632, 2015.

[22] S. Paul and I. Koley, "Corrosion inhibition of carbon steel in acidic environment by papaya seed as green inhibitor," Journal of Bio- and Tribo-Corrosion, vol. 2, no. 2, pp. 2-11, 2016.

[23] V. Sivakumar, K. Velumani, and S. Rameshkumar, "Colocid dye-a potential corrosion inhibitor for the corrosion of mild steel in acid media," Materials Research, vol. 21, no. 4, Article ID e20170167, 2018.

[24] J. Aljourani, M. A. Golozar, and K. Raeissi, “The inhibition of carbon steel corrosion in hydrochloric and sulfuric acid media using some benzimidazole derivatives," Materials Chemistry and Physics, vol. 121, no. 1-2, pp. 320-325, 2010.

[25] J. Aljourani, K. Raeissi, and M. A. Golozar, "Benzimidazole and its derivatives as corrosion inhibitors for mild steel in $1 \mathrm{M}$ $\mathrm{HCl}$ solution," Corrosion Science, vol. 51, no. 8, pp. 1836-1843, 2009.

[26] P. R. Ammal, A. R. Prasad, and A. Joseph, "Comparative studies on the electrochemical and physicochemical behaviour of three different benzimidazole motifs as corrosion inhibitor for mild steel in hydrochloric acid," Egyptian Journal of Petroleum, vol. 27, no. 4, pp. 1067-1076, 2018.

[27] A. Popova, E. Sokolova, S. Raicheva, and M. Christov, "AC and DC study of the temperature effect on mild steel corrosion 
in acid media in the presence of benzimidazole derivatives," Corrosion Science, vol. 45, no. 1, pp. 33-58, 2003.

[28] F. M. Mahgoub, F. M. Al-Nowaiser, and A. M. Al-Sudairi, "Effect of temperature on the inhibition of the acid corrosion of steel by benzimidazole derivatives," Protection of Metals and Physical Chemistry of Surfaces, vol. 47, no. 3, pp. 381-394, 2011.

[29] A. Ghanbari, M. M. Attar, and M. Mahdavian, "Corrosion inhibition performance of three imidazole derivatives on mild steel in 1M phosphoric acid," Materials Chemistry and Physics, vol. 124, no. 2-3, pp. 1205-1209, 2010.

[30] P. Niamien, A. A. Koffi, and A. Trokourey, "Adsorption and inhibitive effects of 2-thiobenzylbenzimidazole (TBBI) at aluminium alloy AA3003/1 M hydrochloric acid interface," International Research Journal of Pure and Applied Chemistry, vol. 2, no. 4, pp. 286-304, 2012.

[31] M. Yadav, D. Behera, S. Kumar, and R. R. Sinha, "Experimental and quantum chemical studies on the corrosion inhibition performance of benzimidazole derivatives for mild steel in HCl," Industrial \& Engineering Chemistry Research, vol. 52, no. 19, pp. 6318-6328, 2013.

[32] L. A. Nnanna, I. O. Owate, and E. E. Oguzie, "Inhibition of mild steel corrosion in $\mathrm{HCl}$ solution by pentaclethra macrophylla bentham extract," International Journal of Materials Engineering, vol. 4, pp. 171-179, 2014.

[33] F. O. Edoziuno, A. A. Adediran, B. U. Odoni, A. D. Akinwekomi, O. S. Adesina, and M. Oki, "Optimization and development of predictive models for the corrosion inhibition of mild steel in sulphuric acid by methyl-5-benzoyl-2benzimidazole carbamate (mebendazole)," Cogent Engineering, vol. 7, no. 1, Article ID 1714100, 2020.

[34] F. O. Edoziuno, B. U. Odoni, A. A. Adediran, J. O. Okeniyi, and E. T. Akinlabi, "Analyses of the gravimetric and electrochemical effects of $\mathrm{C}_{16} \mathrm{H}_{13} \mathrm{~N}_{3} \mathrm{O}_{3}$ on mild steel corrosion in $0.5 \mathrm{M} \mathrm{H}_{2} \mathrm{SO}_{4}$," Journal of Physics: Conference Series, vol. 1378, Article ID 032064, 2019.

[35] M. Oki, E. Charles, C. Alaka, and T. K. Oki, "Corrosion inhibition of mild steel in hydrochloric acid by tannins rom Rhizophora racemosa," Materials Sciences and Applications, vol. 2, no. 6, pp. 592-595, 2011.

[36] A. Nahlé, I. I. Abu-Abdoun, and I. Abdel-Rahman, "Inhibition of mild steel corrosion by 3-benzoylmethyl benzimidazolium hexafluoroantimonate in acidic solution," International Journal of Corrosion, vol. 2012, Article ID 246013, 10 pages, 2012.

[37] F. El-hajjaji, I. Merimi, L. Ouasif et al., "1-Octyl-2-(octylthio)$1 \mathrm{H}$-benzimidazole as a new and effective corrosion inhibitor for carbon steel in $1 \mathrm{M} \mathrm{HCl,"} \mathrm{Portugaliae} \mathrm{Electrochimica} \mathrm{Acta,}$ vol. 37, no. 3, pp. 131-145, 2019.

[38] S. S. Al-Taweel, K. W. S. Al-Janabi, H. M. Luaibi, A. A. AlAmiery, and T. S. Gaaz, "Evaluation and characterization of the symbiotic effect of benzylidene derivative with titanium dioxide nanoparticles on the inhibition of the chemical corrosion of mild steel," International Journal of Corrosion and Scale Inhibition, vol. 8, no. 4, pp. 1149-1169, 2019.

[39] D. S. Zinad, Q. A. Jawad, M. A. M. Hussain, A. Mahal, L. Mohamed, and A. A. Al-Amiery, "Adsorption, temperature and corrosion inhibition studies of a coumarin derivatives corrosion inhibitor for mild steel in acidic medium: gravimetric and theoretical investigations," International Journal of Corrosion and Scale Inhibition, vol. 9, no. 1, pp. 134-151, 2020.

[40] O. L. Riggs, Corrosion Inhibition, C.C. Nathan, Houston, TX, USA, 2nd edition, 1973.
[41] E. E. Oguzie, "Influence of halide ions on the inhibitive effect of Congo red dye on the corrosion of mild steel in sulphuric acid solution," Materials Chemistry and Physics, vol. 87, no. 1, pp. 212-217, 2004.

[42] A. Al-amiery, A. Kadhum, A. H. Alobaidy, A. Mohamad, and P. Hoon, "Novel corrosion inhibitor for mild steel in $\mathrm{HCl}$," Materials, vol. 7, no. 2, pp. 662-672, 2014.

[43] M. P. Desimone, G. Gordillo, and S. N. Simison, "The effect of temperature and concentration on the corrosion inhibition mechanism of an amphiphilic amido-amine in $\mathrm{CO}_{2}$ saturated solution," Corrosion Science, vol. 53, no. 12, pp. 4033-4043, 2011.

[44] L. Nnanna and I. Owate, "Electrochemical study of corrosion inhibition of mild steel in acidic solution using gnetum africana leaves extracts," British Journal of Applied Science \& Technology, vol. 5, no. 6, pp. 556-567, 2015.

[45] S. C. Nwanonenyi, I. C. Madufor, P. Uzoma, and I. C. Chukwujike, "Corrosion inhibition of mild steel in sulphuric acid environment using millet starch and potassium iodide," International Research Journal of Pure and Applied Chemistry, vol. 12, no. 2, pp. 1-15, 2016. 